\title{
PENDIDIKAN ISLAM DAN TEKNOLOGI DIGITAL SERTA EFEKTIVITASNYA DALAM MENDUKUNG TEORY TAXONOMY BLOOM
}

\author{
Ridwan \\ SMA Negeri 2 Pamekasan \\ ridwanpamekasan@gmail.com
}

\begin{abstract}
Digital technology plays an important role for the 21st century in helping human activities with the type and kinds of works. In Islamic terminology, the technological advancement as a platform for everyone to pay "shadaqoh" and getting information and knowledge as well as need. The world has always been inverted with the internet, covering a wide range of applications needed by humans. Applications is like google, facebook, yahoo, e-mail, whatsaap, Instagram, twiter, blogs and others are very easily accessible in various places without insulation. Implementing of Taxonomy Bloom through digital technology is a necessity. The domains of cognitive and psychomotor learning can be linked to the internet application of the constrained hierarchy of the taxonomy. Examples of Word, Excell, Power Point, Chrome, Mozilla Firefox, Internet Explorer, Facebook, Twitter, Instagram, Goolgle, Yahoo, MSN can be applied to the realm of cognitive learning by remembering, understanding, analyze (analyze), evaluate (evaluate) and create (creat) as a form of the realization of learning outcomes based on digital technology. Applications that can be applied include to distribute the material, reroute, submit opinions on some articles online by using the application in accordance with the facilities or softwere relevant to produce products such as making bullet, pointing, create a social networking group or provide a brief comment on the article in webs available. The purpose of this paper is to analyze the development of world technology. Communicate the progress of digital technology in the world of Islamic education and how to apply and utilization to support the application of Taxonomy Bloom's theory.
\end{abstract}

Key word:Education, Information Technology and Taxonomy Bloom

\begin{abstract}
Abstrak
Teknologi digital memainkan peran penting untuk abad 21 dalam membantu aktivitas manusia dengan jenis dan macam pekerjaannya. Dalam terminologi Islam, kemajuan teknologi ini sebagai ajang bagi semua orang untuk bershodaqoh dan wasilah informasi dan pengetahuan sesuai kadar dan kemampuannya. Dunia


teknolgidigital selalu didentikkan dengan dunia internet, yang didalamnya mengcover berbagai macam aplikasi yang dibutuhkan oleh manusia. Aplikasi yang berwujud google, facebook, yahoo, email, whatsaap, Instagram, twiter, blog dan lainya yang sangat mudah diakses diberbagai tempat tanpa sekat. Mengimplementasikan Taxonomy Bloom melalui teknologi digital suatu keniscayaan. Ranah belajar kognitif dan psikomotorik bisa dihubungkan dengan aplikasi internet disesuaikan batasan hirarki pada taxonomy tersebut. Contoh Word, Excell, power point, Chrome, Mozilla firefox, internet explorer, Facebook, twitter, instagram, goolgle, yahoo, dapat diaplikasikan pada ranah belajar kognitif dengan hirarki mengingat (remembering), memahami (understanding), mengalipkasikan (application), menganalisis (analyzing), Evaluasi (evaluing) dan mencipta (creating) sebagai bentuk perwujudan hasil belajar dengan berbasis pada teknologi digital. Aplikasi yang dapat diterapkan antara lain meresum materi, menarasikan ulang, menyampaikan pendapat pada beberapa artikel online dengan cara memanfaatkan aplikasi sesuai dengan fasilitas atau softwere yang relevan dengan menghasilkan produk antara lain membuat bullet, pointing, membuat group dijejaring sosial atau memberikan komentar singkat pada artikel di webs yang tersedia. Tujuan dari penulisan ini adalah untuk mengalinalisis perkembangan teknologi dunia. Mengkomunikasikan kemajuan teknologi digital dalam dunia pendidikan Islam serta cara penerapan dan pemanfaatannya untukmendukung penerapan teori Taxonomy Bloom dalam pembelajaran.

Keyword: Pendidikan Islam, Teknologi Informasi dan Taxonomi Bloom.

\section{Pendahuluan}

Dunia teknologi makin pesat perkembangannya, tidak hanya menyangkut perangkat keras, tapi juga perangkat lunak. Teknologi dengan segala kunggulan membawa angin segar bagi kehidupan manusia dalam mengurangi beban pekerjaan. Kemudahan, kecepatan, efesiensi dan keefektivan merupakan piranti utama dalam mereduksi basis beban kerja dalam berbagai macam bentuk dan posisi dari pekerjaan tersebut. Teknologi informasi memainkan peran penting untuk abad ke-21dalam membantu aktivitas manusia dengan jenis dan macam pekerjaannya. Dunia pengetahuan tidak luput dari imbas perkembangan teknologi ini dalam memberikan informasi dan wawasan. Sudah dapat dipastikan bahwa kemajuannya menjadikan banyak orang tidak pelit untuk menyediakan segala informasi yang dibutuhkan. Dalam persfektif keislaman, kemajuan teknologi informasi sebagai ajang bagi semua orang untuk bershodaqoh informasi dan pengetahuan sesuai kadar dan kemampuan tentang 
Ridwan, Pendidikan Islam dan Teknologi Digital serta Efektivitasnya dalam Mendukung Teory Taxonomy Bloom

pengetahuan yang dimiliki. dunia teknologi informasi identik dengan dunia internet, yang didalamnya mengcover berbagai macam aplikasi yang dibutuhkan oleh manusia. Internet bukan space kikir dalam berbagi dan berbudi, tapi merupakan lahan subur untuk mengakses teks dan konteks kebutuhan manusia yang merasa haus akan informasi dan pengetahuan. Aplikasi pencari informasi (google, yahoo) dan aplikasi medai sosial (whatsApp, facebook, instagram, twiter, dll dan lainya yang sangat mudah diakses diberbagai tempat tanpa sekat. Ruang sangat privasi sekalipun tidak lepas dari jangkauan teknologi ini.

Adalah Alvin Tofler yang menyatakan era informasi sebagai zaman angkasa luar (space era), era elektronik (electronic era), desa global (global village), zaman teknetronik (technetronic age), revolusi saintifik-teknologis (scientific technological revolustion). ${ }^{1}$ Untuk mengakses informasi lewat internet tidak membutuhkan perangkat yang terlalu ribet, dengan gatget sederhana dapat mengakses di berbagai tempat sesuai kebutuhannya. Informasi yang dapat menembus tembok tebal dengan membuat kanal secara alami, merambat ke berbagai macam sektor kehidupan. Antara lain pendidikan, ekonomi, politik, cultur, sosial dan juga batas-batas negara yang hilang.

Sejalan dengan itu Naisbitt mengatakan perkembangan teknologi informasi telah mengubah produk konsumen elektronik (televisi, telepon, dan komputer) menjadi media interaktif, dengan individualisasi kegiatan menonton televisi, berbelanja di rumah, perbankan di rumah, pemesanan tempat duduk pesawat dan kamar hotel, berita, olah raga, video game, film, MTV, perpustakaan, yang kesemuanya tersedia menurut pilihan dan permintaan konsumen. ${ }^{2}$

Arus teknologi yang negative transformation karena liarnya perilaku manusia dalam memanfaatknyaan. Lakon bersambung yang berkonotasi negatif nampak pada pemanfaatannya untuk menyebarkan paham radikalisme dan terorisme, transaksi narkoba, perdagangan manusia, penipuan, pembegalan, pornografi dan pornoaksi, perbuatan asusila, pembunuhan karakter, dan pelacuran, yang sesungguhnya merupakan virus melumpuhkan dengan cara kerja seperti membunuh dengan benang sutra.

Imbas tersebut dapat diminimalkan bahkan dapat dihilangkan dengan mengaktifkan nurani positif sebagai bentuk resipien dengan antibodi yang cukup, agar

\footnotetext{
${ }^{1}$ Ahmad Sonhadji. Manusia, Teknologi, dan Pendidikan Menuju Peradaban Baru. Malang: UM Press, 2012. .13-14 ${ }^{2}$ Ibid, . 50
} 
kehadiran era informasi sebagai berkah bukan sebagai musibah. Kehadiran teknologi informasi dapat membantu manusia mempercepat pekerjaan dan memenuhi aspek kebutuhan sambil merancang kebutuhan yang lain. Teknologi hadir bukan untuk mengubah diorama peradaban, tapi sebagai pelengkap akan kemajuan itu sendiri.

Tidak dapat dihindarinya dampak negatif adalah suatu keniscayaan, tapi ketika nilai-nilai positif dalam aplikasi teknologi dan aplikasinya lebih masiv penggunaannya, maka eksis negatif akan mudah untuk diatasinya. Diibaratkan kanopi tumbuhan yang rimbun, rumput di bawahnya pasti akan mati.

Benang merah geliat kehidupan teknologi informasi dapat dilihat juga dari penggunaan aplikasi berbasis komputer yang menjadi bagian unsur penting dalam berbagai bidang, dan khususnya bidang pendidikan. Lembaga pendidikan sudah mengkoneksikan sebagian besar sistem manjemennya dalam upaya memudahkan semua stakeholder dalam mengakses informasi sesuai dengan kebutuhannya.

Untuk mengurangi akses negatif dan memunculkan aura positif dengan pada dunia informasi harus dicari pola pendidikan yang dapat mengintegrasikan dan mengkorelasi secara kolektif dan proporsional. Dunia pendidikan tidak mungkin menolak kehadiran era ini, sesuai dengan apa yang dikatakan oleh Iqbal "on this road halt is out of lace. Static condition means death. Those who terried even a while will be crushed". 3

Pendidikan Islam yang merupakan bagian sistem pendidikan nasional harus mencari rohnya sendiri agar tidak tergerus oleh teknologi informasi yang semakin masif. Evolusi dalam setiap kegiatan akademik dan non akademik sebagai bentuk implementasi pendidikan terus menerus harus dilakukan. Pengunaan aplikasi teknologi informasi kekinian sebagai bentuk respon kemajuan tidak boleh stagnan. Artinya perangkat sarana dan prasarana serta sumber daya manusia sebagai penopang arus utama kegiatan pendidikan diusahakan kecukupannya serta pemberdayaan sumber dayanya perlu ditingkatkan dan di diperbaharui secara terus menerus. Proses pendidikan yang dilakukan dapat mengakselarasi setiap gerak kemajuan dan kompatibel dengan kontek ruang dan waktu.

Kebijakan komprehensif dengan memadukan akar budaya dan mengadopsi kajian akademis barat dan Islam merupakan tuntutan agar tidak tergilas oleh era ketiga 
Ridwan, Pendidikan Islam dan Teknologi Digital serta Efektivitasnya dalam Mendukung Teory Taxonomy Bloom

(informasi) ini. Pendidikan Islam sebagai epicentrum dari kecerdasan intelengensi (organised inteligence) mempunyai tugas untuk mengembangkan ilmu pengetahuan dan teknologi dan memobilasi masyarakat yang beradab dengan macam model pendidikan yang diterapkan. Dengan kontek itu, pendidikan Islam bertugas melestarikan dan mengembangkan ilmu pengetahuan yang sesuai dengan cita-cita etika dan sistem nilai masyarakatnya.

Dunia pembelajaran sebagai agen perubahan (agent of change), tidak luput dari imbas kemajuan teknologi. Berbagai macam teori yang mengiringi dalam pelaksanaannya, memunculkan berbagai macam strategi, pendekatan, metode yang variatif dipandu dengan aplikasi dalam menghadirkan kondisi kontektual dari ruang eksternal menuju ruang internal. Kelas dalam ruangan bukan lagi tempat magic sebagai sarana pendukung tunggal dalam tafsir proses belajar mengajar. Penggunaan PC (personal computer) dengan berbagai varian mikro dan makro dipadu dengan LCD (liquid crystal display) yang menghadirkan berbagai macam juta warna tampilan sehingga materi pembelajaran menjadi menarik. Isi materi yang berisi kontektualisasi berkelindan dengan metode menghasilkan situasi menyenangkan dalam proses pembelajaran. Tujuan pembelajaran yang mengacu pada taxonomy Bloom mengalami diakronisasi yang berujung pada perubahan cara berfikir orang yang belajar. Ranah belajar kognitif, psikomotik dan afektif dengan berbagai macam bentuk operasionalnya dapat dituntaskan sesuai dengan dimensi ruang dan waktu belajar. Paparan di atas menimbulkan pertanyaanbagaimana perkembangan teknologi dunia itu?, Bagaimana pendidikan Islam mengkomunikasikan kemajuan teknologi informasi/informasi? dan bagaimana teknologi informasi mendukung teori Bloom dalam penbelajaran?

\section{Teknologi Dunia dan Perkembangannya}

Perkembangan teknologi tinggi selama kurang lebih tiga dasawarsa terjadi dihampir bidang kehidupan, misalnya di pabrik, kantor, sistem komunikasi, transportasi, sistem perawatan kesehatan, dan pendidikan. Ciri-ciri teknologi tinggi/sentuh tersebut antara lain adanya kesimbangan antara material teknologi dengan nalar, pikir, jiwa yang menjadi yang tereduksi menjadi nilai-nilai spiritual, memiliki pola dan proses rumit/dinamis, bersifat manusiawi, sebagai pembebas belenggu perbudakan teknologi, serta mempertinggi kelongaran pilihan individu dan kompensasi. 
Semakin komplek tata ekonomi dunia, tidak ada satupun negara yang dapat hidup tanpa ketergantungan dengan negara lain. Kontek negara yang kemudian bergeser menjadi global village menggeser sendi-sendi pengelolaan ekonomi dari lokal (nasional) menjadi transnasional. Internasionalisasi ekonomi bergerak menuju lintasan antar negara tanpa garis demarkasi.

Keadaan dunia yang semakin penuh resiko dan memiliki derajat ketidakpastian tinggi memacu manusia untuk dapat memprakirakan masa depan. Keprihatinan masa lalu tentang pencemaran lingkungan dan ketergantungan terhadap sumber daya yang tidak dapat diperbaharui (unreneweble resources) dapat dijadikan pelajaran betapa bahayanya menggunakan pendekatan jangka pendek. Pendekatan jangka panjang mutlak diperlukan untuk mempertahankan kelangsungan hidup (survival) manusia di abad elektornik.

Semakin besar dan cepatnya arus informasi menyebabkan struktur hirarki kurang dapat memenuhi kebutuhan dalam menyerap dan mengelola informasi. Serta menbuat keputusan secara cepat atas dasar informasi tersebut. Interaksi antar individu dalam suatu organisasi semakin dirasa pentingnya. Inilah yang mendorong lahirnya jaringan-jaringan informasi (information networks) yang menerobos dibalik hirarki yang ada.

Salah satu kecendrungan ialah pilihan indvidu yang semula terbatas, pada abad informasi pilihannya menjadi banyak dan longgar. Ini sangat dirasakan pada pola keluarga, peran wanita, sifat pekerjaan, jaringan komunikasi, dan kebhinnekaan.

Terdapat tiga prasarat dasar untuk berpartisipasi penuh dalam masyarakat informasi (information society), yaitu akses pada telepon, televisi dan komputer. Era informasi dapat dipahami sebagai satu era yang mengharuskan penggunaaninternet sebagai perangkat kerja dalam kehidupan sehari-hari. Tidak hanya berbasis pada kelompok organisasi, masyarakat atau strata sosial, tapi juga pola kerja personal. Kecepatan dan ketepatan menjadi faktor utama dalam pemanfaatannya. Penggunaan secara masive menyasar semua kanal, entah itu privat atau umum. Informasi menggelinding dari satu wilayah menuju pada wilayah lain termasuk di dalamnya antar negara. Semua kebutuhan informasi dapat di akses begitu rupa tanpa tabir yang menghalangi. 
Ridwan, Pendidikan Islam dan Teknologi Digital serta Efektivitasnya dalam Mendukung Teory Taxonomy Bloom

Teknologi informasi merupakan istilah lain dalam abad informasi. Teknologi ini sebagai kampium bagi masyarakat global untuk mengolah data, memproses, menyusun, menyimpan, memanipulasi, mendapatkan dalam menghasilkan informasi dengan kualitas sesuai selera.

Internet sebagai jaringan global dapat mengkoneksikan berjuta-juta jaringan komputer yang dapat melakukan komunikasi dengan menggunakan standar protokol yang dikenal dengan TCP/IP (Transmition Control Protocol/Internet Protocol) yang dapat menghubungkan masing-masing nomor unik pada setiap jaringannya.

Sebagai sumber daya informasi (internet), dapat menjangkau seluruh informasi tanpa mengenal batas dan waktu. Di samping itu dengan sumber daya informasi yang besar, internet sangat mempengaruhi kehidupan umat manusia. Untuk dunia pendidikan, keberadaannya juga mewakili perpustakaan informasi (informasi library) yang dapat diakses selama 24 jam. Dalam perjalanannya internet sampai saat ini merupakan penyedia jasa terbesar penelusuran informasi baik artikel, jurnal maupun ebook. Para akademisi dan praktisi dunia pendidikan atau dunia penelitian dapat menghimpun materi sesuai dengan kebutuhan sebagai penunjang kapabiltas keilmuannya.

Internet inilah merupakan teknologi paling canggih dari sekian teknologi yang tergolong pada scope teknologi informasi. Bahkan internet dapat dianggap sebagai forum diskusi global dimana antara pemateri dan audien dapat bertemu secara langsung atau tidak tergantung dari kontek kebutuhan dan pembicaraan yang disepakati. Sebagai alat untuk kulaan berbagai macam referensi akademik dengan sejuta model demonstrasi keterampilan, internet juga menyediakan berbagai aneka macam hiburan, sosial, ekonomi, pendidikan, budaya dan keagamaan tanpa mengenal batas-batas geografis. Base data yang begitu lengkap dan perpustakaan yang bersifat multi media, menjadikan internet dipandang sebagai kumpulan masyarakat dunia dalam bentuk yang berbeda.

Karena besarnya pengaruh internet, maka juga mempengaruhi cara pandang masyarakat, khususnya masyarakat dalam mengakses segala informasi yang dibutuhkan. Berbarengan dengan maka menjadi penting untuk diketahui manfaat dari internet tersebut yaitu: (1) Interactive comunication yang menjembatani komunikasi personal atau kelompok tanpa dibatasi ruang dan waktu. Aplikasi ini antara lain video confering, internet reley, chat dan internet phone. (2) expert acces, dimana para pengguna dapat belajar secara pada pakar sesuai bidang keahlian yang rata-rata tidak 
pelit dalam berbagi ilmu dan keahlian. Banyak diantara pakar tersebut dengan seneng hati menjawab pertanyaan yang diajukan oleh audiens. (3)library acces, tidak terbantah lagi bahwa dunia internet nisa membawa insan akademik mengakses perpustakaan informasi beberapa perguruan tinggi termashur baik di dalam maupun di luar negeri. (4) Alat bantu pengembangan pengetahuan dan pengembangan. (5) Collaboration, dunia akademik dan dunia penelitian tidak dapat mengurung diri akan perkembangan teori dan berbagai praktik, oleh sebab itu sangat dibutuhkan semangat kerja sama yang sangat menguntungkan dalam rangka kegiatan tersebut. munculnya fenomena baru tidak dapat ditangkap dan dipahami oleh sebagaian besar masyarakat, khususnya masyarakat akademik. Maka dari itu sangat penting bekerja sama dalam rangka menjelaskan pemahaman baru yang berhubungan dengan dunia sain atau yang lain ${ }^{4}$.

Fungsi-fungsi yang lain masih banyak, akan tetapi urgensinya tidak jauh berbeda apa yang sudah di paparkan di atas. Namun sekarang tinggal bagaimana dunia pendidikan Isalm memanfaatkan teknologi ini secara bermakna dalam mengimbangi kemajuan dunia industri dengan segala kegiatan dan perangkatnya sebagai salah satu tujuan bagi lulusan dunia pendidikan. Mungkin kalau meminjam istilahnya Robert maltus dunia dengan peradabannya serta teknologi sebagai penyokong utamanya seperti deret ukur, sementara dunia pendidikan dengan segala aktifitasnya seperti deret hitung.

\section{Sistem Pendidikan Bernafaskan Islam}

Era global yang penuh dengan paradoks berimbas pada semua bidang kehidupan. Berbagai macam peristiwa membuktikan bahwa keinginan untuk berubah kadang melebihi perkiraan. Sebagai contoh penguatan identitas kesukuan baik itu empiris maupun virtual, sehingga suku-suku yang mendiami suatu negara dan sudah lama berasimilasi, pada akhirnya ingin berpisah sesuai dengan identitas kesukuan tersebut, cermin besarnya adalah negara Rusia, Balkan, Eropa Timur sampai kepada Afrika yang mengalami keretakan akibat egoisme kesukuan tersebut. Hak asasi dengan segala tuntutannya menggelinding di seantero kolong langit agar semuanya setara, khususnya kalau merujuk pada jenis kelamin dan bahkan yang tidak masuk akal persamaan pada transgender dan kelompoknya. Pariwisata yang dulu bukan merupakan

${ }^{4}$ Zainudin, zazlina. Pola Pemanfaatan Internet oleh Mahasiswa Program Magister Ilmu Hukum Program Pasca Sarjana Universitas Sumatra Utara. Jurnal Studi Perpustakaan dan Informasi , Vol 2, No.1. 2006.. 37 
Ridwan, Pendidikan Islam dan Teknologi Digital serta Efektivitasnya dalam Mendukung Teory Taxonomy Bloom

primadona dari aset negara, sekarang menjadi gadis cantik yang lemah gemulai sehingga secara masive dipasarkan dalam rangka mendongkrak pendapatan negara. Rangkaian contoh tersebut sebagian kecil adanya paradoks pada dunia global yang tidak dapat diprediksikan. Semakin menjadi paradok ketika teknologi informasi dengan kekuatannya mengubah mindset para penduduk di berbagai penjuru dunia dengan segala kejadian dan persahabatan dan segala bentuk informasi di dalamnya tanpa dapat dihambat. Informasi sebagai bagian dari pengetahuan umat manusia dengan cepat dapat diakses dengan berbagai macam analisis di dalamnya.

Dunia pendidikan Islam kecipratan juga dampak tersebut, diantaranya adalah bagiamana sikap hedonis, budaya materialisme dan konsumerisme, persamaan hak, konflik berbagai belahan dunia, adu domba dalam politik, kemajuan teknologi informasi, menjadi menu harian baik lewat layar kaca atau dunia maya dari mulai bangun tidur sampai tidur kembali. Sehingga dunia pendidikan yang memiliki tujuan mulya harus bertarung meminimalisir dampak kurang baik atau mencerahkan kepada semua pemangku kepentingan dengan segala kekuatannya.

Teknologi informasi tidak mungkin ditolak, akan tetapi bagaimana teknologi dihadapi sehingga yang muncul adalah hakikat dari kegunaannya dan nilai-nilai positif menjadi bagian dari interaksi sosial dan kultural sebagai jiwa dari kemajuan teknologi informasi tersebut.

Untuk meningkatkan dan mendayagunakan potensi yang dimiliki, manusia memerlukan suatu wahana yang disebut sistem pendidikan. Sebagai suatu sistem pendidikan terdiri dari masukan (input), yaitu manusia yang memiliki potensi dan kemampuan (manusia sebagai kholifah), proses atau transformasi yang mengubah masukan menjadi keluaran, melalui penguasaan IPTEK dan etika serta moralitas yang baik (akhlaqul Karimah), dan keluaran (output) memiliki karakteristik yang didasari oleh kewajiban manusia yang selalu mengabdi kepada Allah SWT (Ila Liya'budun) dimanapun dia berada. Sedangkan hasil (outcome) adalah terwujudnya masyarakat yang berperadaban tinggi, penuh dengan kemakmuran dan pengampunnan (baldatun Thoyyibatun warabbun ghopur) dan masyarakat yang sejahtera(Qoryah Thayyibah). Sistem pendidikan ini dalam lingkup lokal, regional, nasional dan global ${ }^{5}$.

\footnotetext{
${ }^{5}$ Ahmad Sonhadji. Manusia, Teknologi, dan Pendidikan Menuju Peradaban Baru. Malang: UM Press, 2012. .41
} 
Agar sistem pendidikan yang diinginkan tercapai maka kemudian Nurcholish Madjid menyarankan adanya kearifan menunda kesenangan sementara demi kebahagiaan masa depan yang lebih besar dan hakiki ${ }^{6}$. Dalam mencapai sistem pendidikan yang meningkatkan kemakmuran dan kesejahteraan persfektif pendidikan Islam mensyaratkan tiga hal yang harus dipenuhi yaitu, pertama, penyediaan sarana dan prasarana yang memadai dan pembukaan akses ke seluruh masyarakat. Kedua, akses yang mudah kepada perkembangan ilmu pengetahuan di dunia. Karena perekaman ilmu pengetahuan itu ada dalam bahasa-bahasa asing, maka diperlukan kepada penguasaan bahasa asing. Ketiga diperlukannya penerjemahan karya ilmiah dari bahasa asing ke bahasa Indonesia untuk menjembatani kemampuan yang heterogen dalam kemampuan berbahasa asing rakyat Indonensia. Tiga hal di atas bukan syarat mudah untuk dipenuhi ditengah dana yang dimiliki terbatas dan disparitas pendidikan Islam yang sangat nampakketimpangannya, serta kondisi geografis dengan kondisi infrastuktur yang kurang memadai. Alternatif yang memungkinkan adalah mencari satu pola dimana dalam waktu yang bersamaan ketiga-tiganya dalam kebutuhan minimal dapat terpenuhi. Teknologi informasi pada akhirnya akan menjadi kebutuhan pokok dalam melengkapi aktifitas kegiatan pendidikan baik lokal maupun global. Jaringan internet adalah kebutuhan primer (essial) bagi sistem pendidikan Islam sebagai jawaban dari kemajuan teknologi informasi dalam menopang kemajuan sistem pendidikan. Penggunaan LAN (lokal area network) dan WAN (Wide Area Network) dapat digunakan untuk sosialisasi, kebijakan pendidikan, paket-paket pembelajaran, serta jaringan networking antara sekolah dan masyarakat yang majemuk.

Dengan internet dapat menjadi kunci agar dunia pendidikan Islam mempunyai standar yang sama. Kendala berupa jarak dan waktu, merupakan solusi dengan dimanfaatkannya dunia internet. Lembaga pendidikan Islam tidak lagi merasa rendah diri, inferior bahkan merasa terbelakang. Penggunaan teknologi internet sebagai bentuk pembaharuan dalam menuju pendidikan Islam yang berkualitas.

\section{Teknologi Informasi dan Dampaknya Terhadap Dunia Pendidikan Islam}

Pesatnya perkembangan teknologi informasi, khususnya internet memungkinkan pengembangan layanan informasi yang lebih baik dalam institusi pendidikan. Di

\footnotetext{
${ }^{6}$ Madjid Nurcholisc. Indonesia Kita. Jakarta: Gramedia Pustaka Utama. 2003. .152-153
} 
Ridwan, Pendidikan Islam dan Teknologi Digital serta Efektivitasnya dalam Mendukung Teory Taxonomy Bloom

lingkungan pendidikan khususnya pendidikan Islam, pemanfaatan teknologi informasi diwujudkan dalam suatu sistem yang disebut electronic school (e-school) dan e University (e-University). Pengembangan electronic school (e-school) dan e University (e-University) bertujuan untuk mendukung penyelenggaraan pendidikan, sehingga sekolah dapat memberi layanan informasi yang lebih baik kepada komunitasnya, baik di dalam maupun di luar perguruan tinggi tersebut melalui internet. Layanan pendidikan lain yang bisa dilaksanakan melalui internet dan dapat diakses oleh siapa saja yang membutuhkan, sehingga memberikan informasi bagi yang sulit mendapatkannya karena kendala ruang dan waktu.

Teknologi internet menjadikan setiap layanan pada lembaga pendidikan Islam semakin mudah. Berkaca kepada sekolah dengan electronic school (e-school) atau perguruan tinggi dengan $e$ universitynya, sehingga penyelenggaraan dan layanan informasi yang lebih baik pada siswa atau mahasiswa dan masyarakat luas. Layanan yang paling mungkin adalah penyediaan materi kualiah atau pelajaran online, tugas online, pembayaran administarsi online, reseach, perpustakaan dan semua kebutuhan yang menyangkut keterpaduan dan kebutuhan akan layanan perlu menggunakan teknologi informasi (internet).

Dunia pendidikan Islam masa kini dan masa akan datang sebagai bagian dari amanat dari penguasaan IPTEK dalam rangka mengembangkan potensi sumber daya manusia merupakan perintah dari Allah SWT (ulil albab)dan manifestasi manusia yang berahlakul karimah yang akan dicapai melalui proses atau transformasi dalam sisitem pendidikan.

Pendidikan Islam tidak dapat memisahkan diri dari dunia internet,dalam rangka perubahan secara komprehensif tentang konsep pendidikan yang klasik menuju pada pembaharuan dimana batasan ruang dan waktu yang menjadi penghambat, tabirnya semakin lama semakin hilang. Manusia Exellent dan moralitas tinggi dapat diharapkan mengoptimalkan pengabdiannya kepada Allah SWT sebagaimana Firman Allah “ dan aku tidak ciptakan jin dan manusia melainkan mereka menyembahku” (QS. AzZariat:56)

Maka dari itu pengelolaan pendidikan Islam dengan berbasiskan teknologi informasi sebagai perangkat sarana dan prasarananya merupakan kebutuhan utama 
(pokok). Karena bagaimanapun evolusi teknologi informasi akan membawa kemudahan dan keunggulan antara lain sebagai berikut:

(1) Siswa/mahasiswa dapat memanfaat teknologi informasi. Misal, mengambil mata kuliah dari perguruan tinggi yang dikehendaki di seluruh dunia, sementara mahasiswa dan siswa dapat mengikuti pembelajaran dimanapun dia berada. Teknologi internet masa depan yang diakses dengan komputer dan hand phone dapat digunakan dimanapun manusia itu berdomisili. Misal lingkungan air yang menjadi momok karena dapat merusak, teknologi ini pada akhirnya bisa familier terhadap tempat dan kondisi yang sangat ekstrem sekalipun. Begitu juga dengan sistem pancar internetnya juga semakin peka karena teknologinya pasti bermodisikasi secara terus menerus dengan perangkat lunak dan kerasnya yang sangat peka.

(2) Siswa/mahasiswa dapat dengan mudah berguru pada para ahli di bidang yang diminati dan ditekuninya. Teknologi internet membawa masyarakat seluruh dunia untuk saling berinteraksi dan berkolaborasi dengaan tidak didahului oleh saling kenal-mengenal wajah. Di pihak lain dengan terus munculnya generasi Fourth Generation Long Term Evolusian (4G LTE) yang merupakan generasi terbaru dan tercepat dalam mengirim dan menerima informasi melalui jaringan nirkabel atau wareless. Dan yang terbaru sudah menyusul 5G LTE. Dengan perangkat yang semakin sederhana tapi kemampuan tinggi menjadikan masyarakat semakin mudah melakukan hubungan dengan seluruh lapisan masyarakat dibelahan manapun. Sementara itu teknologi fiber dengan jaringan kabel menyebabkan hubungan lalu lintas komunikasi 1000 orang perdetik bahkan bisa lebih.

(3) Kuliah/sekolah sudah bukan masalah lagi. Lokasi dan jarak bukan penghalang, Kemajuan teknologi informasi khususnya internet membawa pada waktu dan jarak semakin dekat. Pertemanan virtual dan proses pendidikan secara virtual bukan hal yang tabu, tapi sudah menjadi keharusan gerak aktifitas masyarakat di bawah kolong langit ini ${ }^{7}$.

\footnotetext{
${ }^{7}$ Suryadi, Siregar. 2003. Pendidikan Teknologi Informasi Peluang dan Tantangan http://personal.fmipa.itb.ac.id/suryadi/files/2007/12/ pendidikan-informatika-dan_orasi-ilmiah-2004.pdf
} 
Ridwan, Pendidikan Islam dan Teknologi Digital serta Efektivitasnya dalam Mendukung Teory Taxonomy Bloom

\section{Dunia Pembelajaran dan Taxonomy Bloom}

Sebagai psikolog dan sosok yang memiliki otoritas dalam pengukuran pendidikan (educational measurment), Benyamin Bloom telah banyak mempengaruhi banyak peneliti. Risetnya tentang pentingnya anak-anak telah menantang pendidik untuk mempertimbangkan kembali prosedur yang ada dalam organisasi sekolah dan alokasi sumber daya. Karyanya yang terakhir mengenai belajar tuntas (mastery learning) berjanji membuka pendekatan baru bagi pendidikan semua anak ${ }^{8}$.

Setelah bekerja di bawah Kepemimpinan Ralph Tyler, Bloom mendapatkan wawasan mendalam tentang teori dan praktik evaluasi pendidikan, suatu istilah yang diciptakan untuk tugas evaluator. Bloom memulai tugas menerjemahkan tujuan pembelajaran melalui perilaku konkret ke dalam instrumen pengukuran, sebuah tugas yang sangat sulit jika harus berhadapan dengan tujuan-tujuan ranah afektif. Buku pertama yang mebahas ranah kognitif dan ditulis oleh Bloom bersama David Krathrol, Taxonomy of Education Objectives. Delapan tahun kemudian yaitu pada tahun 1964 terbitlah jilid ke duanya yang membahas ranah afektif ${ }^{9}$.

Dalam buku tersebut simpulan sederhananya digambarkan bahwa orang belajar memiliki tujuan dalam tiga ranah yaitu kognitif, afektif dan psikomotorik. Ranah kognitif berhubungan dengan memproses informasi, pengetahuan dan keahlian mental. Ranah afektif meliputi fungsi yang berhubungan dengan sikap, emosi serta perasaan. Ranah psikomotorik berhubungann dengan fungsi keterampilan baik kongkrit dan manipulatif serta kemampuan fisik ${ }^{10}$. Inilah yang kemudian dapat dikatakan sebagai babak baru dalam dunia pengajaran sekaligus dunia evaluasi. Penemuannya membuat proses dalam dunia pembelajaran mempunyai indikator jelas terlepas dari kontroversi para pakar yang kurang menyetujuinya. Teori ini kemudian diadopsi oleh banyak lembaga pendidikan di berbagai negara dengan terlebih dahulu dijadikan kebijakan melalui kajian yang komprehemsif disesuaikan dengan kontek kearifan lokal negara tersebut.

\footnotetext{
${ }^{8}$ Joy A Palmer. Ide-ide Brillian 50 Pakar Pendidikan Kontemporer Paling Berngaruh di Dunia Pendidikan Modern. 2015. 171

${ }^{9}$ Ibid. 171

${ }^{10}$ Rahmad. Taksonomi Bloom : Mengembangkan Strategi Berpikir Berbasis TIK

http://gurupembaharu.com/taksonomi-bloom-mengembangkan-strategi-berpikir-berbasis-tik/
} 
Ranah kognitif menggambar kemampuan hirarki berfikir, dengan cara mengekspresikan tahap-tahap dari hirarki tersebut dimana siswa harus menunjukkan kemampuan mengolah pikirannya dengan kemampuan mengaplikasikan teori ke dalam praktik. Juga dengan kata lain teori yang dipelajari tidak berhenti di ruang hampa, akan tetapi menemukan jawabannya lewat keterampilan terbaiknya. Hasil yang didapatkan tentunya sebuah inovasi tingkat tinggi sebagai bentuk produk dari belajarnya.

Konsep tersebut mengalami perbaikan disesuikan dengan perkembangan dan kemajuan jaman serta Ilmu Pengetahuan dan Teknologi (IPTEK). Lorin Anderson adalah orang yang merevisi taksonomi Bloom pada tahun 1990, dan hasilnya perbaikannya dipublikasikan pada tahun 2001 dengan nama Revisi Taksonomi Bloom. Dalam revisi ini ada perubahan kata kunci, pada kategori dari kata benda menjadi kata kerja. Masing-masing kategori masih diurutkan secara hirarkis, dari urutan terendah ke yang lebih tinggi. Ranah kognitif dengan kemampuan berpikir analisis dan sintesis diintegrasikan menjadi analisis saja. Dari jumlah enam kategori pada konsep Bloom terdahulu dari sisi jumlah tidak ada perubahan, karena Anderson memasukkan creatingsebagaikategori baru yang sebelumnya tidak ada.

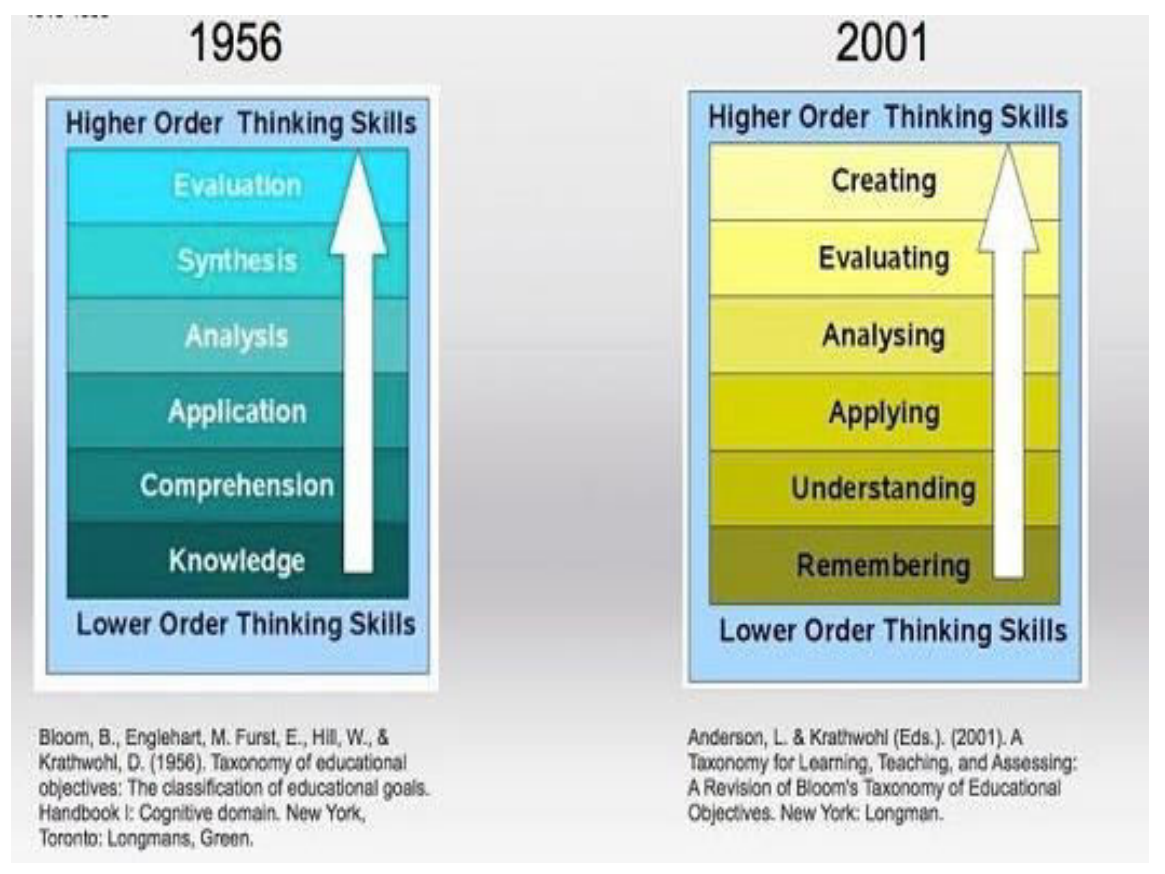


Ridwan, Pendidikan Islam dan Teknologi Digital serta Efektivitasnya dalam Mendukung Teory Taxonomy Bloom

Ranah psikomotor merupakan keterampilan gerak yaitu koordinasi secara fisik dalam menggunakan keterampilannya. Pengembangannya dapat diukur dari kecepatan, ketepatan, jarak, prosedur, atau teknik pelaksanaan. Tingkat penguasaan keterampilan terbagi dalam tujuh kategori, yaitumempersepsikan, menyiapkan, menanggapi respon, mekanis, mengembangkan respon yang kompleks, adaptasi dan orisinalitas. Ranah belajar psikomotorik mengubah cara pandang masyarakat dalam belajar, yaitu paradigma belajar masa lalu yang penuh dengan penguasaan teoritis bergeser pada nilainilai pragmatis dengan ciri bahwa belajar tidak hanya diukur dari seberapa banyak teori yang dikuasai, namun perlu di konkritkan dengan seberapa terampil siswa menerapkan teori yang dikuasai menjadi karya nyata atau bagaimana teori dapat mengatasi problem kehidupan secara arif dan kreatif. Pendapat itu sejalan dengan pemikiran Charles Handy, seorang bussiness philosopher bahwa belajar ilmu pengetahuan dengan berbagai teori sangat penting akan tetapi yang lebih penting adalah apa yang harus dilakukan dengan ilmu pengetahuan tersebut ${ }^{11}$

Ranah Afektif merupakan ranah sikap, dimana kompetensi ini ada enam kategori yaitu menerima, menjalankan, menghargai, mernghayati dan mengamalakan ${ }^{12}$. Secara konkrit pengalaman belajar yang perlu dicapai siswa antara lain mengamati dan menirukan contoh/model/panutan, mendatangi objek studi yang dapat memupuk pertumbuhan nilai, berbuat atau berpartisipasi aktif sesuai dengan tuntutan nilai yang dipelajari ${ }^{13}$.

Menjadi pertanyataan sekarang bagaimana caranya teori Bloomdapat diimplemmentasikan dengan dasar aplikasi teknologi informasi (internet). Sebelum menjawab pertanyaan di atas maka menjadi penting terlebih dahulu untuk mereformasi isi pendidikan yang sering dikeluhkan tertinggal jauh dari tuntutan kehidupan. Adalah Tony Wagner menuangkan hasil risetnya dalam sebuah buku yang berjudul The Global Achievement Gap. Dalam buku tersebut Wagner mengajukan statemen betapa pentingnya the survival skill (meliputi critikal thinking and problem solving, collaboration accros network and leading by influence, agility and adaptability, initiative and entrepreneulialism, efective oral and written communication, accessing

\footnotetext{
${ }^{11}$ Samani, Muchlas. Menggagas Pendidikan Bermakna Integrasi Life Skill-KBKI-CTL-MBS. Surabaya:SIC.2007. .97 12 Materi Pelatihan Guru Implementasi Kurikulum 2013. Jakarta: Kementerian Pendidian dan Kebudayaan. 2014.16

${ }^{13}$ Majid, Abdul. Perencanaan Pembelajaran Mengembangkan Stnadar Kompetensi Guru. Jakarata. Remaja Rosda Karya. 2006.. 50
} 
and analyzing information and curiosity and imagination $)^{14}$. Ketika isi dunia pendidikan sudah berubah, tahap berikutnya model dosen dan guru dalam mengajar juga harus ada perubahan plus kompetensi juga harus berubah. Alasannya adalah tidak mungkin Dosen atau guru hanya menggunakan model ceramah, sementara di mahasiswa/siswa sudah pamilier dengan dunia gawai atau teknologi informasi. Pembelajaran yang dilaksanakan tidak hanya fokus pada mata kuliah atau mata pelajaran yang diampu, akan tetapi bisa menjadi interdisiplin bahkan multi disiplin mata kuliah atau mata pelajaran. Ungkapan yang mengatakan "bad teacher tells, good teacher shows, great teacher inspire"s bukan hanya sebagai idiom saja, akan tetapi merupakan kewajiban guru dalam menjalan tugas dan fungsinya ${ }^{15}$.

Untuk menjawab kegalauan akan teori Bloom pada abad digital ini, maka pedagogi dengan prinsip-prinsip pendidikan dan metode harus beradaptasi dengan perubahan teknologi digital,ini termasuk taksonomi Bloom. Taksonomi ini telah direvisi disesuaikandengan teknologi digital. Istilah baru yang menjadi kata kunci atau kata kerja operasional telah ditambahkan untuk mewakili fungsi dari teknologi ini. Istilahistilah yang ada pada diagram gambar di bawah iniberasal dari taksonomi asli. Selain itu, komunikasi sebagai aspek yang penting juga digambarkan dalam taksonomi Bloom digital ini. Gambaran penggunaan aplikasi teknologi digital pada hirarki berfikir taxonomy Bloomadalah sebagai berikut ${ }^{16}$.

Tabel 1. Digitalisasi taxonomi Bloom

\section{Mengingat (Remembering)}

\begin{tabular}{|c|l|l|l|}
\hline No & \multicolumn{1}{|c|}{$\begin{array}{c}\text { Kegiatan } \\
\text { Pembelajaran }\end{array}$} & Software/fasilitas pendukung & \multicolumn{1}{|c|}{ Produk } \\
\hline 1 & Memberi nama file & Word, excell, power point & $\begin{array}{l}\text { Memberikan kode pada } \\
\text { penamaan file }\end{array}$ \\
\hline 2 & $\begin{array}{l}\text { Meresume materi } \\
\text { dalam bentuk bullet } \\
\text { pointing }\end{array}$ & Power point, word, & $\begin{array}{l}\text { Membuat bullet, pointing, } \\
\text { colouring mengenai } \\
\text { informasi penting }\end{array}$ \\
\hline
\end{tabular}

\footnotetext{
${ }^{14}$ Samani Muchlas. Semua di Handle Google Tugas Guru Apa. Surabaya: University Press. 2016.Hlm 3

${ }^{15}$ Ibid 164

${ }^{16}$ Rahmad. Taksonomi Bloom : Mengembangkan Strategi Berpikir Berbasis TIK.

http://gurupembaharu.com/taksonomi-bloom-mengembangkan-strategi-berpikir-berbasis-tik/ diakses 5 April 2018
} 
Ridwan, Pendidikan Islam dan Teknologi Digital serta Efektivitasnya dalam Mendukung Teory Taxonomy Bloom

\begin{tabular}{|l|l|l|l|}
\hline 3 & $\begin{array}{l}\text { Mengidentifikasi web } \\
\text { dan nara sumber yang } \\
\text { mendukung materi } \\
\text { pelajaran }\end{array}$ & $\begin{array}{l}\text { Chrome, mozilla firefox, } \\
\text { internet explorer }\end{array}$ & $\begin{array}{l}\text { Membookmarking/ } \\
\text { favouriting web atau nara } \\
\text { sumber terkait }\end{array}$ \\
\hline 4 & $\begin{array}{l}\text { Menarasikan ulang } \\
\text { topik diskusi pada situs } \\
\text { jejaring sosial }\end{array}$ & $\begin{array}{l}\text { Facebook, twitter, WhatApp } \\
\text { Instagram }\end{array}$ & $\begin{array}{l}\text { Membentuk group di } \\
\text { jejaring sosial }\end{array}$ \\
\hline 5 & $\begin{array}{l}\text { Mengulang penjelasan } \\
\text { kembali informasi dari } \\
\text { internet }\end{array}$ & $\begin{array}{l}\text { Search engine : goolgle, yahoo, } \\
\text { msn }\end{array}$ & $\begin{array}{l}\text { Melakukan pencarian data } \\
\text { melalui search engine }\end{array}$ \\
\hline
\end{tabular}

\section{Memahami (Understanding)}

\begin{tabular}{|l|l|l|l|}
\hline No & \multicolumn{1}{|c|}{$\begin{array}{c}\text { Kegiatan } \\
\text { Pembelajaran }\end{array}$} & Software/fasilitas pendukung & \multicolumn{1}{|c|}{ Produk } \\
\hline 1 & $\begin{array}{l}\text { Menyampaikan } \\
\text { pendapat tentang satu } \\
\text { atau lebih berita yang } \\
\text { dimuat secara online }\end{array}$ & Republika.com; merdeka.com & $\begin{array}{l}\text { Memberikan komentar } \\
\text { singkat pada artikel di web }\end{array}$ \\
\hline 2 & $\begin{array}{l}\text { Membedakan } \\
\text { dokumen pribadi } \\
\text { berdasarkan mata } \\
\text { pelajaran }\end{array}$ & Word, excel, powerpoint, & $\begin{array}{l}\text { Mengklasifikasikan file, } \\
\text { website dan bahan ke } \\
\text { dalam folder }\end{array}$ \\
\hline 3 & $\begin{array}{l}\text { Mendiskusikan topik } \\
\text { materi pelajaran } \\
\text { tertentu }\end{array}$ & $\begin{array}{l}\text { Forum diskusi di internet } \\
\text { (www.forumsains.com, } \\
\text { forum.detik.com) }\end{array}$ & $\begin{array}{l}\text { Menyampaikan opini } \\
\text { dalam forum internet }\end{array}$ \\
\hline 4 & $\begin{array}{l}\text { Menjelaskan ulang } \\
\text { materi pelajaran ke } \\
\text { dalam blog }\end{array}$ & $\begin{array}{l}\text { wordpress.com, blogspot.com, } \\
\text { multiply.com }\end{array}$ & $\begin{array}{l}\text { Laporan berupa catatan } \\
\text { dan tugas harian dalam } \\
\text { blog }\end{array}$ \\
\hline 5 & $\begin{array}{l}\text { Menerjemahkan materi } \\
\text { pelajaran berbahasa } \\
\text { asing dari internet }\end{array}$ & $\begin{array}{l}\text { Internet, google translate, } \\
\text { translation2.paralink.com }\end{array}$ & $\begin{array}{l}\text { Materi pelajaran dalam } \\
\text { dua bahasa }\end{array}$ \\
\hline
\end{tabular}

\section{Mengaplikasikan (Application)}

\begin{tabular}{|c|c|c|c|}
\hline No & $\begin{array}{c}\text { Kegiatan } \\
\text { Pembelajaran }\end{array}$ & Software/fasilitas pendukung & Produk \\
\hline 1 & Menguji pemahaman & Program e-learning & Menjalankan sebuah \\
\hline
\end{tabular}


FIKROTUNA: Jurnal Pendidikan dan Manajemen Islam Volume 7, Nomor 1, Juli 2018

\begin{tabular}{|l|l|l|l|}
\hline & $\begin{array}{l}\text { materi pelajaran } \\
\text { melalui e-learning }\end{array}$ & program \\
\hline 2 & $\begin{array}{l}\text { Mengilustrasikan } \\
\text { proses biologi dalam } \\
\text { bentuk flow chart }\end{array}$ & $\begin{array}{l}\text { Microsoft office vissio, power } \\
\text { point, word }\end{array}$ & $\begin{array}{l}\text { Mengaplikasikan beberapa } \\
\text { program }\end{array}$ \\
\hline 3 & $\begin{array}{l}\text { Mengaplikasikan } \\
\text { program excel untuk } \\
\text { penyelesaian soal } \\
\text { MIPA }\end{array}$ & Excel & $\begin{array}{l}\text { Memodifikasi aplikasi } \\
\text { program }\end{array}$ \\
\hline 4 & $\begin{array}{l}\text { Menguji kemampuan } \\
\text { daya nalar }\end{array}$ & $\begin{array}{l}\text { Web games online, } \\
\text { games.co.id, sudoku }\end{array}$ & $\begin{array}{l}\text { Memainkan sebuah games } \\
\text { online berbasis pendidikan }\end{array}$ \\
\hline 5 & $\begin{array}{l}\text { Menyusun fakta-fakta } \\
\text { sejarah menjadi sebuah } \\
\text { kliping / catatan sejarah } \\
\text { online }\end{array}$ & $\begin{array}{l}\text { Web, buku sejarah, google, } \\
\text { ziddu.com, rapidshare }\end{array}$ & $\begin{array}{l}\text { Mengupload materi atau } \\
\text { informasi ke dalam sebuah } \\
\text { web }\end{array}$ \\
\hline
\end{tabular}

\section{Menganalisis (Analysing)}

\begin{tabular}{|c|c|c|c|}
\hline No & $\begin{array}{c}\text { Kegiatan } \\
\text { Pembelajaran }\end{array}$ & Software/fasilitas pendukung & Produk \\
\hline 1 & $\begin{array}{l}\text { Mengintegrasikan data, } \\
\text { tabel, grafik dan flow } \\
\text { chart ke dalam sebuah } \\
\text { artikel }\end{array}$ & Word, excel, visio, blog/web & $\begin{array}{l}\text { Mengintergrasikan beberapa } \\
\text { sumber data ke dalam satu } \\
\text { web/blog }\end{array}$ \\
\hline 2 & $\begin{array}{l}\text { Menghubungkan topik } \\
\text { mata pelajaran yang } \\
\text { dipelajari dengan } \\
\text { informasi terupdate } \\
\text { saat ini }\end{array}$ & $\begin{array}{l}\text { Google, yahoo dan search } \\
\text { engine lainnya }\end{array}$ & $\begin{array}{l}\text { Menetapkan link web yang } \\
\text { berhubungan dengan materi } \\
\text { yang sedang dipelajari }\end{array}$ \\
\hline 3 & $\begin{array}{l}\text { Menguraikan biografi } \\
\text { tentang tokoh sains } \\
\text { terkemuka }\end{array}$ & Google, yahoo, wikipedia & Biografi tokoh sains \\
\hline 4 & $\begin{array}{l}\text { Mereview dan menilai } \\
\text { informasi hasil } \\
\text { browsing }\end{array}$ & Google, yahoo & $\begin{array}{l}\text { Memvalidasi ketelitian dan } \\
\text { kebenaran data yang berasal } \\
\text { dari web }\end{array}$ \\
\hline 5 & $\begin{array}{l}\text { Mengorganisir data } \\
\text { yang dimiliki sesuai } \\
\text { dengan mata pelajaran } \\
\text { dan jenis file }\end{array}$ & $\begin{array}{l}\text { Web, blog, pdf, mp2, word, } \\
\text { excel }\end{array}$ & Mengorganisir data online \\
\hline
\end{tabular}

\section{Mengevaluasi (Evaluating)}

\begin{tabular}{|l|c|c|c|}
\hline No & $\begin{array}{c}\text { Kegiatan } \\
\text { Pembelajaran }\end{array}$ & Software/fasilitas pendukung & Produk \\
\hline
\end{tabular}


Ridwan, Pendidikan Islam dan Teknologi Digital serta Efektivitasnya dalam Mendukung Teory Taxonomy Bloom

\begin{tabular}{|l|l|l|l|}
\hline 1 & $\begin{array}{l}\text { Merekomendasikan } \\
\text { web/sumber online } \\
\text { sebagai bahan belajar }\end{array}$ & Google, yahoo, web, blog & $\begin{array}{l}\text { Daftar dan link web yang } \\
\text { direkomendasi }\end{array}$ \\
\hline 2 & $\begin{array}{l}\text { Mengkritisi sebuah } \\
\text { topik yang sedang } \\
\text { dibahas }\end{array}$ & Forum diskusi online & $\begin{array}{l}\text { Mengomentari topik } \\
\text { tertentu pada forum diskusi }\end{array}$ \\
\hline 3 & $\begin{array}{l}\text { Menilai kelayakan } \\
\text { suatu karya untuk } \\
\text { ditampilkan ke publik }\end{array}$ & Forum online sekolah, & $\begin{array}{l}\text { Memoderatori sebuah forum } \\
\text { diskusi }\end{array}$ \\
\hline 4 & $\begin{array}{l}\text { Memantau kemajuan } \\
\text { kolaborasi }\end{array}$ & Web/blog/forum & $\begin{array}{l}\text { Membangun kolaborasi dan } \\
\text { jaringan di situs social }\end{array}$ \\
\hline 5 & $\begin{array}{l}\text { Menghitung efisiensi } \\
\text { kerja sebuah aplikasi } \\
\text { program }\end{array}$ & Excel, e-learning & $\begin{array}{l}\text { Menguji prosedur kerja } \\
\text { sebuah aplikasi program }\end{array}$ \\
\hline
\end{tabular}

\section{Menciptakan (creating)}

\begin{tabular}{|c|c|c|c|}
\hline No & $\begin{array}{c}\text { Kegiatan } \\
\text { Pembelajaran }\end{array}$ & Software/fasilitas pendukung & Produk \\
\hline 1 & $\begin{array}{l}\text { Menciptakan aplikasi } \\
\text { program sederhana }\end{array}$ & Power point, excel & $\begin{array}{l}\text { Mengembangkan kreasi } \\
\text { dengan power point, } \\
\text { Mengembangkan kreasi } \\
\text { kreasi dengan excel }\end{array}$ \\
\hline 2 & $\begin{array}{l}\text { Menciptakan aplikasi } \\
\text { multimedia sederhana }\end{array}$ & Adobe photoshop & $\begin{array}{l}\text { Mengembangkan animasi } \\
\text { sederhana untuk alat peraga } \\
\text { belajar }\end{array}$ \\
\hline 3 & $\begin{array}{l}\text { Medesain tampilan } \\
\text { blog/website pribadi }\end{array}$ & $\begin{array}{l}\text { Webhosting gratis } \\
\text { (www.rumahweb.com, } \\
\text { www.webhost.com, } \\
\text { www.webs.com ); blog } \\
\text { wordpress, blogspot }\end{array}$ & Website / blog pribadi \\
\hline 4 & $\begin{array}{l}\text { Berkolaborasi } \\
\text { menghasilkan suatu } \\
\text { karya untuk } \\
\text { dipublikasikan secara } \\
\text { online }\end{array}$ & Internet, blog, website & $\begin{array}{l}\text { Mengembangkan kerja sama } \\
\text { mengembangkan karya tulis } \\
\text { bersama berbasis jaringan } \\
\text { internet. }\end{array}$ \\
\hline 5 & $\begin{array}{l}\text { Membuat rekaman } \\
\text { kegiatan sekolah/ karya } \\
\text { dalam bentuk audio } \\
\text { (podcasting) }\end{array}$ & $\begin{array}{l}\text { Software atau pemutar } \mathrm{mp} 3 \text {, } \\
\text { perekam audio, }\end{array}$ & $\begin{array}{l}\text { Podcast untuk } \\
\text { dipublikasikan secara online }\end{array}$ \\
\hline 6 & $\begin{array}{l}\text { Merancang web/blog } \\
\text { komersial }\end{array}$ & Web, blog & Memiliki toko usaha online \\
\hline
\end{tabular}




\section{Penutup}

Pendidikan Islam tidak pernah bisa melepaskan diri dari kemajuan teknologi digital. Isi dan proses pendidikan harus dikelola dengan mengikuti teori terkini yang dipadukan dengan kemajuan teknologi itu sendiri. Tantangan dunia pendidikan Islam yang harus mampu menjawab kebutuhan integrasi tradisi modern dalam bidang ilmu pengetahuan dan teknologi harus direspon dengan cara memodifikasi sistem pembelajaran dengan memandang bahwa manusiaitu mahkluk ideal yang membawa manfaat. Manusia sebagai khalifah di muka bumi menjadi fitrah tersendiri dengan diberinya kemampuan dan potensi di dalam dirinya oleh Allah untuk menguasai dan mengembangkan IPTEK serta memiliki akhlak yang mulia dan mengabdi kepada Allah SWT. Pada akhirnya Islam sebagai rahmatan lil alamin menjadi produk bukan hanya untuk orang Islam sendiri akan tetapi untuk semua makhluk.. Digitalisasi teori Bloom merupakan salah pintu masuk dalam melakukan reformasi bahkan revolusi untuk menciptakan manusia unggul sesuai perintah agama Islam. Manusia unggul dengan cara berfikir tingkat tinggi (High Order Thinking Skill) menjadi kenyataan sambil mengasah nurani sehingga memiliki perilaku yang bermanfaat kepada semua makhluk di muka bumi ini. 
Ridwan, Pendidikan Islam dan Teknologi Digital serta Efektivitasnya dalam Mendukung Teory Taxonomy Bloom

\section{Daftar Pustaka}

.2014. Materi Pelatihan Guru Implementasi Kurikulum 2013. Jakarta: Kementerian Pendidian dan Kebudayaan.

Madjid, Nurcholis. 2003. Indonesia Kita. Jakarta:Gramedia Pustaka Utama..

Majid, Abdul. 2006. Perencanaan Pembelajaran Mengembangkan Standar Kompetensi Guru. Jakarata: Remaja Rosda Karya

Palmer, Joy. A. 2015. Ide-ide Brillian 50 Pakar Pendidikan Kontemporer Paling Berngaruh di Dunia Pendidikan Modern. Jogyakarta: IrCiSod.

Samani Muchlas. 2016. Semua di Handle Google Tugas Guru Apa. Surabaya: University Press.

Samani, Muchlas. 2007. Menggagas Pendidikan Bermakna Integrasi Life Skill-KBKI$C T L-M B S$. Surabaya: SIC

Siregar, Suryadi. 2003. Pendidikan Teknologi Informasi Peluang dan Tantangan. Jakarta: Gramedia

Sonhadji. Ahmad. 2012. Manusia, Teknologi, dan Pendidikan Menuju Peradaban Baru. Malang: UM Press. Tantangan. Diperoleh dari http://personal. fmipa. itb. ac.id / suryadi/files/2007/12/

Zainudin, zazlina. 2006. Pola Pemanfaatan Internet oleh Mahasiswa Program Magister Ilmu Hukum Program Pasca Sarjana Universitas Sumatra Utara. Jurnal Studi Perpustakaan dan Informas. Vol. 2, No. 1.

.2018, 4 Maret. Republika.co.id. Berita/kolom/wacana/18/02/18p4ut4h396.

Churches, Andrew. 2009, 5 April. “Bloom's Digital Taxonomy”. Diperoleh dari http://edorigami.wikispaces.com/file/view/bloom\%27s\%20Digital\%20taxonomy $\% 20$ v3.01. pdf/65720266/bloom\%27s\%20Digital\%20taxonomy\%20v3.01.pdf

Rahmad. 2018, 5 April. "Taksonomi Bloom: Mengembangkan Strategi Berpikir Berbasis TIK”. Diperoleh dari http://gurupembaharu.com/taksonomi-bloommengembangkan-strategi-berpikir-berbasis-tik/ 